\title{
Zgodnje sporazumevalne zmožnosti dojenčkov in malčkov: Študija v Sloveniji
}

\author{
Ljubica Marjanovič Umek*, Urška Fekonja Peklaj, Gregor Sočan in Luka Komidar \\ Oddelek za psihologijo, Filozofska fakulteta, Univerza v Ljubljani
}

\begin{abstract}
Povzetek: Razvoj zgodnjih sporazumevalnih zmožnosti poteka v obdobjih dojenčka in malčka zelo hitro tako s kakovostnega kot tudi količinskega vidika. V pričujoči raziskavi smo želeli prvič podrobneje raziskati starostne razlike v zgodnjih sporazumevalnih zmožnosti slovenskih dojenčkov in malčkov. V vzorec je bilo vključenih 512 dojenčkov in malčkov, starih od 8 do 30 mesecev, njihove sporazumevalne zmožnosti pa so bile ocenjene z Listo razvoja sporazumevalnih zmožnosti: Besede in geste in Listo razvoja sporazumevalnih zmožnosti: Besede in stavki (Marjanovič Umek, Fekonja Peklaj, Sočan in Komidar, 2011). Dobljeni rezultati so pokazali, da v obdobju med 8. in 30. mesecem starosti prihaja do pomembnih starostnih razlik na različnih področjih sporazumevalnih zmožnosti (npr. pri sporazumevalnih in simbolnih gestah, besednjaku, dolžini in slovnični zapletenosti stavkov). Poleg tega smo ugotovili, da se različna področja sporazumevalnih zmožnosti dojenčkov in malčkov zmerno do visoko pozitivno povezujejo med seboj. Analiza učinka spola na sporazumevalne zmožnosti dojenčkov in malčkov je pokazala, da se dojenčki/dojenčice in malčki/malčice, stari od 8 do 16 mesecev, med seboj niso statistično pomembno razlikovali v sporazumevalnih zmožnostih. Statistično pomembne razlike med spoloma so bile pri malčkih, starih od 16 do 30 mesecev, in sicer so imele malčice večji besednjak kot malčki.
\end{abstract}

Ključne besede: sporazumevalne zmožnosti, geste, besednjak, slovnica, dojenčki, malčki

\section{Early communicative competences of infants and toddlers: A Slovenian study}

Ljubica Marjanovič Umek, Urška Fekonja Peklaj, Gregor Sočan, and Luka Komidar Department of Psychology, Faculty of Arts, University of Ljubljana, Slovenia

\begin{abstract}
Communicative competences develop rapidly in the periods of infanthood and toddlerhood, both from the qualitative and quantitative point of view. In the following study we aimed to analyse for the first time the age differences in early communication competences of Slovenian infants and toddlers. The sample included 512 infants and toddlers, aged from 8 to 30 months; their communication competences were assessed with the Communicative Development Inventory: Words and Gestures and Communicative Development Inventory: Words and Sentences (Marjanovič Umek, Fekonja Peklaj, Sočan, and Komidar, 2011). The obtained results suggest that in the period between 8 and 30 months of age there are significant age differences within different areas of communication competences (e.g. communicative and symbolic gestures, vocabulary, length and grammatical complexity of sentences). In addition, we found moderate to high positive correlations between different areas of infants' and toddlers' communication competences. The analysis of the effect of gender on the communication competences of infants and toddlers showed that girls and boys aged 8 to 16 months did not differ significantly in their communicative competences. Significant gender differences were found in toddlers aged from 16 to 30 months: girls expressed a more extensive vocabulary.
\end{abstract}

Key words: communicative competences, gestures, vocabulary, grammar, infants, toddlers

\footnotetext{
${ }^{*}$ Naslov/Address: red. prof. dr. Ljubica Marjanovič Umek, Oddelek za psihologijo, Filozofska fakulteta, Univerza v Ljubljani, Aškerčeva 2, 1000 Ljubljana, e-mail: ljubica.marjanovic@ff.uni-lj.si
}

Članek je licenciran pod pogoji Creative Commons Attribution 4.0 licence. / The article is licensed under a Creative Commons Attribution 4.0 International License. 
Razvoj besednjaka poteka v obdobju malčka zelo hitro (Brooks in Meltzoff, 2008; Fenson idr., 2004; Marjanovič Umek, Fekonja, Kranjc in Bajc, 2008), pri čemer razumevanje besed $\mathrm{v}$ razvoju časovno predhodi rabi leteh (Bates in Goodman, 2001; Fenson idr., 2004; Reynell, 1979). Dojenčki za sporazumevanje z odraslimi najprej rabijo glasove, in sicer jok, vokalizacijo, bebljanje in naključna posnemanja glasov brez razumevanja njihovega pomena (Bates in Goodman, 2001; Siegler, 1998). Potrebo in željo po socialnem sporazumevanju sporočajo tudi $\mathrm{z}$ vključevanjem v skupno vezano pozornost ter z gestami (Parise, Friederici in Striano, 2010). Več avtorjev navaja, da dojenčki že razlikujejo posamezne skupine glasov med seboj ter da so občutljivi na razlike med glasovi v posamezni besedi (npr. Eimas in Miller, 1991; Mehler in Dupoux, 1994). Mandel, Jusczyk in Pisoni (1995) na podlagi izsledkov raziskave ugotavljajo, da dojenčki, stari 4;6 mesecev, prepoznajo svoje ime in ga poslušajo pomembno dlje kot druge besede $\mathrm{s}$ podobnim ali različnim vzorcem glasov, čeprav nujno še ne razumejo pomena in referenčne funkcije svojega imena. Jusczyk in Hohne (1997) podobno navajata, da si že osemmesečni dojenčki zapomnijo določene zveze glasov, saj dalj časa poslušajo seznam besed iz zgodbe, ki so jo poslušali pred dvema tednoma, kot seznam besed, ki v zgodbo niso bile vključene. V 9. oz. 10. mesecu se dojenčki vedno pogosteje odzivajo na določene besede, najpogosteje so to imena družinskih članov ali poimenovanje rutinskih dejavnosti (Nelson, 1996). Desetmesečni dojenčki pa po mnenju nekaterih avtorjev (npr. Tomasello in Bates, 2001) že namerno posnemajo glasove, ki jih slišijo $\mathrm{v}$ govoru odraslih, vendar pri tem še ne razumejo njihovega pomena.

\section{Pomen uporabe gest in simbolnih dejanj za razvoj dojenčkove sporazumevalne zmožnosti}

$\mathrm{V}$ drugi polovici prvega leta dojenček $\mathrm{v}$ namene sporazumevanja uporablja tudi geste, in sicer protoimperativne geste, s katerimi izraža svoje želje in potrebe, in protodeklerativne, s katerimi želi vzbuditi pozornost drugega, da bi z njim vzpostavil stik oz. povezanost (Karmiloff in Karmiloff - Smith, 2001; Whitehead, 2005). Dojenčkove geste pogosto spremlja vokalizacija in neposreden očesni stik $\mathrm{z}$ osebo, s katero se sporazumeva (Messinger, Fogel in Dickson, 1999). R. Brooks in Meltzoff (2008) ugotavljata, da sta pogostnost dojenčkovega sledenja s pogledom pogledu odrasle osebe in pogostnost kazanja na predmete med 10. in 11. mesecem starosti pomembna napovednika hitrosti naraščanja obsega malčkovega besednjaka do drugega leta starosti. Malčki z gestami in kazanjem na predmete dodatno pojasnjujejo pomen svojih enobesednih izjav, ko npr. besedo "še" povežejo z odprto dlanjo, ali pa s prstom pokažejo na predmet, ki ga želijo imeti (Smith in Cowie, 1993). Iverson, Caprici in Caselli (1994) navajajo, da je približno polovica šestnajstmesečnih malčkov, vključenih v njihovo raziskavo, še vedno uporabljala $\mathrm{V}$ sporazumevanju $\mathrm{z}$ drugimi več simbolnih gest kot besed, kasneje pa so bile v sporazumevanju prevladujoče besede.

Malčki po prvem letu starosti uporabljajo geste tudi za označevanje predmetov in dejavnosti v igri. Več avtorjev (npr. Goodwin in Acredolo, 1993; Lewis, Boucher, Lupton in Watson, 2000) poroča o pomembni povezanosti med razvojem uporabe gest $\mathrm{v}$ simbolni igri in razvojem govora, saj gre v vseh primerih za malčkovo zmožnost simbolnega predstavljanja. Tako jezik kot simbolna dejanja malčku/otroku omogočata preizkušanje različnih simbolnih pretvorb, pri čemer simboli lahko predstavljajo npr. besede, oponašanje glasov, geste ali predmetne zamenjave (McCune-Nicolich, 1981, Whitehead, 1999). L. McCune-Nicolich (1981) meni, da so prvi simboli v malčkovi igri in govoru neposredno povezani z njegovim ravnanjem in so zato predsimbolni. Malček v igri prepoznava predmete kot so npr. glavnik ali steklenička za dojenčka ter se z njimi sicer igra simbolno, vendar na konvencionalen način, npr. češe dojenčka, pije iz prazne steklenice. Istočasno $\mathrm{z}$ razvojem preprostih simbolnih dejanj se tudi v govoru razvijejo analogni predsimbolni glasovi, ki predhodijo pravim besedam in vključujejo ponavljajoče skupine glasov, katerih pomen malček najpogosteje pojasni $\mathrm{z}$ uporabo gest (npr. na predmet pokaže z roko ali pa ga skuša prijeti). Po mnenju avtorice malček v zgodnji simbolni igri kaže poznavanje nekaterih osnovnih dejavnosti odraslega ter se zaveda možnosti vključevanja teh dejavnosti v svojo igro. Več avtorjev ugotavlja, da približno $\mathrm{v}$ osemnajstem mesecu starosti prihaja do pomembnih razvojnih sprememb v malčkovi zmožnosti predstavljanja. Takrat večina malčkov že govori prve besede (Bates, Dale in Thal, 1995; Fenson idr., 1994), izvaja simbolna dejanja, ki vključujejo tudi druge osebe ali igrače (npr. igračo dojenčka ali odraslo osebo) ter povezuje sosledje posameznih igralnih dejanj (npr. pretvarja se, da pije iz prazne steklenice, nato pa s steklenico nahrani dojenčka; Belsky in Most, 1981; O'Reilly in Bornstein, 1993). Dojenčki in malčki, stari od osem do štiriindvajset mesecev, ki so že sposobni oblikovati simbolne pretvorbe, hitreje dosegajo razvojne mejnike $\mathrm{v}$ govoru na področju besednjaka in slovnice jezika (Doswell, Lewis, Sylva in Boucher, 1994; McCune, 1995). P. Lyytinen, A.-M. Poikkeus in M.-L. Laakso (1997) so ugotovile, da so 18mesečni malčki, ki so prej govorili prvo besedo, v svojo igro vključevali več simbolnih dejanj kot malčki, ki so začeli govoriti kasneje.

\section{Razvoj malčkovega besednjaka in usvajanja začetnih slovničnih pravil jezika}

Večina malčkov govori prvo besedo $\mathrm{v}$ starosti med dvanajstim in dvajsetim mesecem, čeprav so med njimi velike individualne razlike (Fernald, Pinto, Swingley, Weinberg in McRoberts, 2001; Tomasello in Bates, 2001). M. Whitehead (1999) navaja tri kriterije, ki določajo prvo besedo, in sicer malček rabi besedo spontano; vedno ob isti dejavnosti ali v istem okolju; besedo prepozna tudi odrasla oseba, ki $\mathrm{z}$ malčkom komunicira $\mathrm{v}$ različnih situacijah. V obdobju, ko njegov besednjak obsega do 
10 besed, malček najpogosteje govori besede, ki bi jih težko uvrstili v posamezne skupine besed, značilnih za govor odraslega, saj predstavljajo posnemanje oglašanja živali in predmetov. Te besede malček govori v visoko strukturiranih situacijah in so zato pogosto razumljive le $\mathrm{v}$ konkretnem kontekstu in osebam, ki so skupaj $\mathrm{z}$ njim vključene $\mathrm{v}$ določeno dejavnost (Caselli, Casadio in Bates, 2001). Ker je malčkova raba prvih besed nepredvidljiva in jih rabi v omejenih situacijah, so starši, ki malčka poslušajo med različnimi, posebej še rutinskimi dejavnostmi, lahko veljavni ocenjevalci njegovega zgodnjega besednjaka (Bornstein in Haynes, 1998; Dale, Bates, Reznick in Morisset, 1989; Feldman idr. 2000). Prve besede $\mathrm{v}$ malčkovem besednjaku so najpogosteje vezane na poimenovanje stvari $\mathrm{v}$ neposrednem okolju in označujejo družinske člane, hrano, živali, dele telesa, rutinske dejavnosti ali pa gre za enostavne prošnje (Caselli idr., 2001; Karmiloff in Karmiloff - Smith, 2001; Nelson, 1973; Siegler, 1998). Prvih 50 besed govorijo malčki v starostnem razponu od enega do dveh let starosti (npr. Harris, 1993; Messer, 1999; Reich, 1986). Po osemnajstem mesecu starosti malčkov besednjak zelo hitro raste (Bates in Goodman, 2001; Fernald idr., 2001). E. Bates in sodelavci (1994) so v svoji raziskavi ugotovili, da so malčki, stari 12 mesecev, govorili od 0 do 52 besed; malčki, stari 16 mesecev, od 0 do 347 besed in malčki, stari 30 mesecev, od 208 do 675 besed. E. Bates in J. C. Goodman (2001) pa sta ugotovila, da se v razvoju malčkovega besednjaka pojavita dva pomembna skoka, in sicer prvi med 16. in 20. mesecem in drugi med 24. in 30. mesecem starosti. Velikost besednjaka se $\mathrm{v}$ tem obdobju lahko poveča za nekaj besed dnevno (Siegler, 1998; Tomasello, 2001). Vsi malčki skokov v razvoju besednjaka ne dosegajo pri enakih starostih (Hoff, 2001; Reznick in Goldfield, 1994). Bornstein in sodelavci (2004) so ob analizi besednjaka 20-mesečnih malčkov, ki so govorili različne jezike (španski, nizozemski, francoski, hebrejski, italijanski, korejski in angleški jezik) in živeli v različnih jezikovnih okoljih, ugotovili, da so v besednjaku vseh malčkov prevladovali samostalniki nad ostalimi besednimi vrstami, vendar le pri malčkih, ki so govorili več kot 50 besed. V besednjaku malčkov, ki so govorili do 50 besed, je bil delež samostalnikov primerljiv z deležem glagolov. $Z$ usvajanjem slovnice jezika in $\mathrm{z}$ razvojem večbesednih izjav pa $\mathrm{v}$ malčkovem besednjaku narašča tudi število pridevnikov, s katerimi poimenuje lastnosti predmetov in odnosov med njimi ter število funkcijskih besed (Caselli idr., 2001; Owens, 1996).

Razvoj malčkovega besednjaka ne poteka ločeno od usvajanja slovnice jezika, saj malčki v govoru odraslih redko slišijo samostojne besede, izolirane od drugih. Besede praviloma slišijo kot dele večbesednih izjav, s katerimi se posamezniki sporazumevajo (Tomasello in Bates, 2001). Usvajanje slovnice jezika od malčka/otroka zahteva prepoznavo posameznih besed in vzorcev glasov v posameznih besedah. Nekateri avtorji (npr. Marchman in Bates, 1994) menijo, da zmore malček prehod od oblikovanja enobesednih k oblikovanju dvobesednih izjav takrat, ko njegov besednjak obsega od 50 do 100 besed.
Crain in D. Lillo-Martin (1999) navajata, da približno eno leto in pol star malček začenja povezovati dve samostojni besedi v besedno zvezo, pri čemer je intonacija, s katero izgovori vsako izmed njiju enaka tisti, ki je značilna za izgovorjavo samostojnih besed. Iz kombinacije dveh besed začne malček postopoma oblikovati enostavne dvobesedne izjave, kar mu omogoča, da na nov način organizira, poveže in osmisli lastne izkušnje in socialne odnose (Oppenheim, Emde in Wamboldt, 1996). E. Bates in J. Goodman (2001) navajata, da so vsebina in značilnosti malčkovih prvih kombinacij besed, ki jih poveže v izjave, pomembno povezani z vsebino in značilnostmi malčkovih enobesednih izjav. Obseg besednjaka malčkov, starih 20 mesecev, vključenih $\mathrm{v}$ njuno raziskavo, je visoko napovedoval zapletenost slovnične strukture malčkovega govora pri 28 mesecih. L. D'Odorico in S. Carubbi (2003) pa poudarjata, da je obseg malčkovega besednjaka sicer pozitivno povezan $\mathrm{z}$ njegovo sposobnostjo tvorjenja dvoin večbesednih izjav, vendar ne popolnoma, saj lahko malček z zelo obsežnim besednjakom v svojem govoru rabi le enobesedne izjave.

Malčki, stari od 24 do 30 mesecev, praviloma že oblikujejo izjave, sestavljene iz treh ali štirih besed ter hitro usvajajo slovnična pravila jezika (Siegler, 1998; Smith in Cowie, 1993). Siegler (1998) navaja, da so malčkove prve večbesedne izjave najpogosteje nepopolne, saj malček v njih praviloma izpušča predloge, pomožne glagole in pridevnike, kljub temu pa prenašajo določen pomen in so razumljive odraslim. Malčki že zgodaj v obdobju oblikovanja večbesednih izjav usvojijo osnovni besedni red jezika, ki je najprej ozko vezan le na njim poznane besede, ki jih pogosto slišijo $\mathrm{v}$ izjavah drugih (Akhtar, 2001). Povezovanje besed v pravilno zaporedje malčku omogoča, da so tudi skrajšane in nepopolne izjave najpogosteje razumljive poslušalcu. Usvajanje novih besed in slovničnih pravil, npr. pravil spreganja in sklanjanja, malčku omogoča, da govori tudi o predmetih, ki so odsotni, preteklih dogodkih ali pa sprašuje o predmetih, ki se nahajajo v njegovi okolici (Browne, 1996).

Namen naše raziskave je bil prvič na vzorcu slovensko govorečih dojenčkov in malčkov preučiti starostne razlike v sporazumevalnih zmožnostih dojenčkov/malčkov, starih od 8 do 30 mesecev. Zanimala nas je tudi primerjava med deklicami in dečki. Eden od naših problemov je bil tudi preučiti ali se različna področja sporazumevalnih zmožnosti (npr. sporazumevalne geste, razumevanje in raba besed, povprečna dolžina stavka) dojenčkov in malčkov povezujejo med seboj.

\section{Metoda}

\section{Udeleženci}

V vzorec je bilo vključenih 512 dojenčkov in malčkov, starih od 8 do 30 mesecev, iz različnih regij Slovenije. 152 dojenčkov in malčkov (72 dojenčkov/malčkov in 80 dojenčic/malčic), je bilo starih od 8 do 16 mesecev, 360 malčkov (186 malčkov in 172 malčic) pa je bilo starih od 
16 do 30 mesecev. Izobrazbena struktura mam dojenčkov in malčkov, starih od 8 do 16 mesecev, je bila naslednja (za 2 mami ni bilo podatka o izobrazbi): 4 mame $\mathrm{z}$ dokončano osnovno šolo, 20 mam z 2- in 3-letno poklicno šolo, 19 mam s 4-letno srednjo šolo, 37 mam $z$ višjo ali visoko šolo, 55 mam s fakulteto in 15 mam $\mathrm{z}$ magisterijem ali doktoratom. Podobna je bila izobrazbena struktura mam malčkov, starih od 16 do 30 mesecev (za 1 mamo ni bilo podatka o izobrazbi): 7 mam $\mathrm{z}$ dokončano osnovno šolo, $58 \mathrm{z}$ 2- in 3-letno poklicno šolo, $82 \mathrm{~s}$ 4-letno srednjo šolo, $85 \mathrm{z}$ višjo ali visoko šolo, $105 \mathrm{~s}$ fakulteto in $22 \mathrm{z}$ magisterijem ali doktoratom. Vsi dojenčki in malčki so bili donošeni, nihče izmed njih ni imel govornih motenj. V vzorec so bili vključeni dojenčki in malčki, za katere so starši dali informirano pisno soglasje za sodelovanje v raziskavi.

\section{Pripomočki}

Sporazumevalne zmožnosti dojenčkov in malčkov, starih od 8 do 16 mesecev, smo ocenili z Listo razvoja sporazumevalnih zmožnosti: Besede in geste (LRSZ: Besede in geste; Marjanovič Umek, Fekonja Peklaj idr., 2011), sporazumevalne možnosti malčkov, starih od 16 do 30 mesecev, pa z Listo razvoja sporazumevalnih zmožnosti: Besede in stavki (LRSZ: Besede in stavki; Marjanovič Umek, Fekonja Peklaj idr., 2011). Listi sta bili ob soglasju avtorjev (Fenson idr., 2004) pripravljeni kot slovenska priredba svetovno uveljavljenega pripomočka za ocenjevanje sporazumevalnih zmožnosti dojenčkov in malčkov s strani staršev The MacArthur-Bates Communicative Development Inventories.

LRSZ: Besede in geste je sestavljena iz dveh delov, in sicer prvega dela Prve besede in drugega dela Dejavnosti in geste. Prvi del Prve besede vključuje štiri področja, in sicer Prvi znaki razumevanja, Izjave, Začetek govora in Besednjak. Področje Prvi znaki razumevanja sestavljajo tri vprašanja o tem, ali dojenček/malček kaže prve znake razumevanja govora $\mathrm{z}$ odzivanjem na znane besede. Področje Izjave vključuje seznam preprostihizjav, za katere starši označijo, ali jih dojenček/malček razume. Področje Začetek govorjenja sestavljata dve vprašanji o tem, ali dojenček/malček ponavlja besede in/ali dele stavkov ter poimenuje stvari v okolici. Področje Besednjak je najbolj obsežno in vključuje seznam 396 besed, ki so razvrščene v 19 skupin (npr. Medmeti, Živali, Besede, s katerimi poimenujemo čas, Pridevniki, Zaimki). Za vsako izmed besed starš označi, ali jo dojenček/malček razume in ali jo tudi govori. Drugi del Dejavnosti in geste vključuje šest področij, in sicer Prve sporazumevalne geste, Igre in rutinske dejavnosti, Dejanja s predmeti, Pretvarja se, da je starš, Posnemanje dejavnosti odraslih in Predmetne zamenjave. Področje Prve sporazumevalne geste vključuje opise gest, ki označujejo dojenčkovo/malčkovo namerno sporazumevanje $\mathrm{z}$ drugimi: geste dajanja, kazanja in iztegovanja ter konvencionalne sporazumevalne geste (npr. »Odkima z glavo.« ali »Pošilja poljubčke z razdalje.«). Področje Igre in rutinske dejavnosti vključuje opise iger in dejavnosti, ki predstavljajo socialne interakcije dojenčka/malčka z odraslimi in so osnova kasnejšim sporazumevalnim zmožnostim (npr. Igra se skrivalnice/ »ku ku«.). Področje Dejanja s predmeti vključuje opise dejanj, ki kažejo na dojenčkovo/malčkovo razumevanje predmetov in njihove ustrezne uporabe (npr. »Natakne si kapo.« ali »Pometa z metlo.«). Področje Pretvarja se, $d a$ je starš vključuje opise dejavnosti, ki se nanašajo na prve oblike pravih simbolnih gest, ki se v dojenčkovi/malčkovi spontani igri navadno razvijejo nekaj mesecev po tem, ko že izvaja dejanja, opisana na področjih Dejanja s predmeti in Posnemanje dejavnosti odraslih (npr. »Dojenčka položi v posteljo.«). Področje Posnemanje dejavnosti odraslih vključuje opise dejanj, ki se nanašajo na dojenčkovo/ malčkovo posnemanje dejavnosti odraslih (npr. »Sesa s sesalnikom.«). Starš za vsako gesto ali dejavnost označi, ali jo malček uporablja oz. izvaja ali ne. Dosežek na področjih Prve sporazumevalne geste in Igre in rutinske dejavnosti se sešteje v delni dosežek, poimenovan Dejavnosti in geste (zgodnje geste), dosežki na področjih Dejanja s predmeti, Pretvarja se, da je starš in Posnemanje dejavnosti odraslih pa v delni dosežek, poimenovan Dejavnosti in geste (pozne geste). Dosežki na vseh petih področjih se seštejejo v skupni dosežek Dejavnosti in geste (skupne geste). Zadnje področje Predmetne zamenjave vključuje vprašanje o tem, ali dojenček/malček med igro oblikuje predmetne zamenjave, ki so pomemben pokazatelj njegove sposobnosti simbolnega pretvarjanja. Zanesljivost liste je razmeroma visoka; alfa koeficient zanesljivosti, izračunan na vzorcu 152 dojenčkov in malčkov, starih od 8 do 16 mesecev, se giblje od 0,79 do 0,99 za različna področja.

LRSZ: Besede in stavki je sestavljena iz dveh delov, in sicer prvega dela Besede, ki jih govorijo malčki, in drugega dela Stavki in slovnica. Prvi del Besede, ki jih govorijo malčki, je sestavljen iz dveh področij, in sicer Besednjak in Pretekli in prihodnji dogodki ter odsotni predmeti in osebe. Področje Besednjak vključuje seznam 680 besed, ki so razvrščene v skupine, npr. Živali, Vozila, Igrače, Vprašalnice, Predlogi in besede, s katerimi poimenujemo kraj ali smer. Za vsako izmed besed starš označi, ali jo malček govori. Področje Pretekli in prihodnji dogodki ter odsotni predmeti in osebe vključuje vprašanja o pogostnosti malčkovih izjav, ki se nanašajo na pretekle in prihodnje dogodke ter odsotne stvari in kažejo na malčkovo sposobnost časovne in prostorske dekontekstualizacije jezika. Drugi del Stavki in slovnica sestavljajo štiri področja, in sicer Oblika in pomen besed, Posploševanje slovničnih pravil, Dolžina stavkov in Zapletenost stavkov. Področje Oblika in pomen besed vključuje vprašanja o pogostnosti malčkove rabe množine, svojine, dovršnih in nedovršnih glagolov in preteklika. Področje Posploševanje slovničnih pravil vsebuje seznam množinskih samostalnikov, ki so zapisani v pravilni in napačni obliki množine, in glagolov, zapisanih v pravilni in napačni obliki prve osebe ednine. Starš označi ali malček pravilno ali nepravilno uporablja določeno slovnično pravilo ali pa nič od tega. Temu področju sledi vprašanje o tem, ali malček že združuje dve ali več besed. Če starši odgovorijo, da malček včasih ali pogosto združuje dve besedi ali več v stavek, odgovarjajo tudi na 
postavke na zadnjih dveh področjih. Področje Dolžina stavkov od staršev zahteva, da napišejo tri najdaljše stavke, ki jih je malček že povedal. Dosežek na tem področju je povprečna dolžina treh najdaljših stavkov, ki jih govori malček. Področje Zapletenost stavkov vključuje pare stavkov; v vsakem paru je prvi stavek z manj zapleteno, drugi pa z bolj zapleteno slovnično strukturo, starši pa označijo tistega, ki je bolj podoben stavku, ki ga govori njihov malček. Zanesljivost liste je razmeroma visoka; alfa koeficient zanesljivosti, izračunan na vzorcu 360 malčkov, starih od 16 do 30 mesecev, se giblje od 0,88 do 0,98 za različna področja. Veljavnost liste je bila na vzorcu 140 malčkov, starih od 16 do 30 mesecev, ocenjena preko ujemanja med ocenami staršev in vzgojiteljic, ki so ocenjevale iste malčke. Povezanosti med ocenami dveh ocenjevalcev so bile zmerne in statistično pomembne na vseh področjih, vključenih v listo, in so se gibale med 0,39 in 0,55 za različna področja (Marjanovič Umek, Fekonja, Podlesek in Kranjc, 2011).

Slovenska priredba list je bila oblikovana tako, da je bila $\mathrm{v}$ obeh listah ohranjena osnovna struktura, torej deli in posamezna področja izvirnih list, hkrati pa so bile upoštevane vse značilnosti slovenskega jezika, tako $\mathrm{z}$ vidika slovnične strukture jezika (npr. tvorjenje množine in dvojine, preteklika in prihodnjika) kot tudi pomena besed (npr. določene živali, značilne za slovenski prostor, imena izštevank). Najbolj je bilo glede na izvirno obliko liste za malčke, stare od 16 do 30 mesecev, spremenjeno področje Posploševanje slovničnih pravil v drugem delu LRSZ: Besede in stavki. To področje je bilo v slovenski obliki liste razširjeno $\mathrm{z}$ večjim številom množinskih samostalnikov, ki so, zaradi neprimerljivosti s samostalniki v angleškem jeziku, vsebinsko drugačni, poleg tega pa je v slovenski obliki staršem dana možnost, da označijo, ali malček množino oblikuje pravilno, nepravilno ali pa ne rabi nobene izmed navedenih oblik (v izvirni obliki so navedene le nepravilne oblike samostalnikov). Podobno velja tudi za seznam glagolov, ki so v izvirni obliki liste navedeni kot nepravilne oblike glagolov v pretekliku, v slovenski obliki pa so zaradi specifičnosti spreganja glagolov zapisani $\mathrm{v}$ pravilni in nepravilni obliki prve osebe ednine; starš pa lahko označi tudi možnost, da otrok ne govori nobene izmed navedenih oblik.

\section{Postopek}

Sporazumevalne zmožnosti dojenčkov in malčkov so ocenjevale mame, ki so bile k sodelovanju povabljene v vrtcih, v katere so bili vključeni njihovi dojenčki in malčki, $\mathrm{v}$ zdravstvenem domu in preko treh spletnih strani, namenjenih staršem. Po zbranih informiranih pisnih soglasjih staršev za sodelovanje $\mathrm{v}$ raziskavi smo LRSZ: Besede in geste in LRSZ: Besede in stavki posredovali mamam na tri načine: mamam dojenčkov in malčkov, ki so bili vključeni v vrtec, so liste posredovale njihove vzgojiteljice; mamam, ki so podpisale soglasje za sodelovanje $\mathrm{v}$ raziskavi $\mathrm{v}$ dispanzerju za predšolske otroke, je liste posredovala pediatrinja; mamam, ki so se na sodelovanje odzvali preko spletnih strani za starše, smo liste posredovali v elektronski obliki. Mame so listo izpolnile doma in jo $\mathrm{v}$ zaprti kuverti vrnile bodisi vzgojiteljici, pediatrinji ali jo po pošti poslale raziskovalcem. Mame, ki so odgovorile na vabilo $\mathrm{k}$ sodelovanju preko ene izmed spletnih strani za starše, so lahko listo dobile tudi elektronsko, jo nato izpolnile ter jo preko e-pošte vrnile raziskovalcem.

\section{Rezultati}

Dojenčke in malčke smo glede na kronološko starost razdelili v pet starostnih skupin: starost 8-12 mesecev, 13-16 mesecev, 16-20 mesecev, 21-25 mesecev in 26-30 mesecev.

\section{Starostne razlike v sporazumevalnih zmožnosti dojenčkov in malčkov, starih od 8 do $\mathbf{3 0}$ mesecev}

Skoraj vsi (89\%) dojenčki, stari 8 in 9 mesecev, kažejo prve znake razumevanja govora (se odzivajo na ime, na "Ne ne" in "Tam, glej!"), medtem ko vsi dojenčki in malčki, stari od 10 do 15 mesecev, kažejo vse prve znake razumevanja govora.

V tabeli 1 so prikazani odstotki dojenčkov/malčkov v posameznih starostnih skupinah, ki nikoli, včasih ali pogosto ponavljajo besede in poimenujejo stvari $\mathrm{v}$ svoji okolici. Vidimo lahko, da večina najmlajših dojenčkov, starih 8 in 9 mesecev, ne ponavlja besed in ne poimenuje stvari v okolici, delež dojenčkov in malčkov, starih 14 in 15 mesecev, ki ponavljajo besede in poimenujejo stvari $\mathrm{v}$ okolju, pa že presega $70 \%$.

Sporazumevalne zmožnosti dojenčkov in malčkov med 8. in 16. mesecem starosti naraščajo. Dojenčki, stari 8 in 9 mesecev, v povprečju razumejo 8 preprostih izjav, malčki, stari 14 in 15 mesecev, pa razumejo v povprečju okoli 23 preprostih izjav. Povprečno število besed, ki jih dojenčki/malčki razumejo in govorijo, narašča s starostjo, pri čemer dojenčki/malčki vseh starosti razumejo več besed kot jih govorijo. Število besed, ki jih dojenčki in malčki razumejo in govorijo, se povečuje s starostjo, in sicer 8 - in 9-mesečni dojenčki razumejo v povprečju 31 besed, 14- in 15-mesečni malčki pa 200 besed; 8- in 9mesečni dojenčki govorijo $\mathrm{v}$ povprečju 2 besedi, 14- in 15-mesečni malčki pa v povprečju 42 besed. Povprečno število sporazumevalnih in simbolnih gest ter dejavnosti (tako zgodnjih kot tudi poznih) s starostjo dojenčkov in malčkov narašča skoraj linearno. Izračunane velikosti učinka starosti $\left(\eta^{2}\right)$ so pokazale, da ima starost dojenčkov in malčkov zmeren do visok učinek na različna področja sporazumevalnih zmožnosti med 8 . in 16. mesecem, in sicer je bil učinek starosti najvišji za dejavnosti in geste in najnižji za rabo besed.

Področje Dejavnosti in geste smo podrobneje analizirali glede na zaporedje razvoja dejavnosti in gest pri različno starih dojenčkih in malčkih. Dejavnosti in geste, ki so bile prisotne pri vsaj $80 \%$ 12-mesečnih dojenčkov, smo poimenovali zgodnje geste. Dejavnosti in geste, ki so 
Tabela 1. Odstotki dojenčkov/malčkov, ki ponavljajo besede in poimenujejo stvari v okolici, v posameznih starostnih skupinah

\begin{tabular}{crrrr}
\hline & \multicolumn{5}{c}{ starost v mesecih } \\
\cline { 2 - 5 } & 8 in 9 & 10 in 11 & 12 in 13 & 14 in 15 \\
\hline ponavlja besede & & & & \\
nikoli & 93 & 43 & 44 & 27 \\
včasih & 7 & 52 & 40 & 49 \\
pogosto & 0 & 5 & 17 & 24 \\
poimenuje stvari & & & & \\
nikoli & 96 & 52 & 35 & 22 \\
včasih & 0 & 33 & 48 & 47 \\
pogosto & 4 & 14 & 17 & 31 \\
\hline
\end{tabular}

bile prisotne pri manj kot $50 \%$ 12-mesečnih dojenčkov in hkrati prisotne pri vsaj $50 \% 15$-mesečnih malčkov, smo poimenovali pozne geste. Redke geste so tiste, ki so bile prisotne pri manj kot $50 \% 15$-mesečnih malčkov.

V tabeli 3 lahko vidimo, da s starostjo malčkov narašča raba poznih in redkih dejavnosti in gest.

Analiza odgovorov mam na vprašanje, ali dojenček/ malček med igro oblikuje predmetne zamenjave, to je eno od področij Dejavnosti in geste, je pokazala, da noben 8- in 9-mesečni dojenček še ni oblikoval predmetne zamenjave, medtem ko jih le-te oblikuje $5 \% 10$ - in 11mesečnih dojenčkov, 32 \% 12- in 13-mesečnih malčkov in $38 \% 14$ - in 15-mesečnih malčkov.

Iz tabele 4 lahko vidimo, da velikost besednjaka malčkov, starih od 16 do in 30 mesecev, razmeroma enakomerno in hitro narašča: 16- in 17-mesečni malčki govorijo v povprečju 54 besed, 28- in 29-mesečni malčki pa 394 besed. Med malčki posamezne starostne skupine so $\mathrm{v}$ velikosti besednjaka razmeroma velike individualne razlike. Tako število pravilnih kotnepravilnih posploševanj slovničnih pravil narašča s starostjo malčkov, medtem ko odsotnost posploševanj slovničnih pravil s starostjo malčkov upada. Malčki vseh starosti v povprečju uporabljajo več pravilnih kot nepravilnih posploševanj. Povprečna dolžina stavkov s starostjo malčkov precej enakomerno narašča: malčki, stari 16 in 17 mesecev, govorijo v povprečju enobesedne stavke, malčki, stari 28 in 29 mesecev, pa govorijo stavke, ki v povprečju vključujejo štiri besede. Malčki, stari od 16 do 21 mesecev, v povprečju govorijo razmeroma majhno število zapletenih stavkov (približno enega do dva zapletena stavka); malčki, stari 22 in 23 mesecev, pa že približno 6 zapletenih stavkov. Število zapletenih stavkov nato enakomerno narašča do približno 16 zapletenih stavkov, ki jih govorijo 28 in 29 mesecev stari malčki. Izračunane velikosti učinka starosti $\left(\eta^{2}\right)$ so pokazale, da ima starost malčkov zmeren do visok učinek na različna področja sporazumevalnih zmožnosti malčkov, starih od 16 do 30 mesecev. Učinek starosti malčkov je bil najvišji za velikost besednjaka in najnižji za nepravilno posploševanje slovničnih pravil.

Rezultati analize odgovorov staršev o tem, ali njihov malček že združuje dve ali več besed, so pokazali, da besede $\mathrm{v}$ stavke združuje približno petina najmlajših malčkov, starih 16 in 17 mesecev, približno polovica malčkov, starih od 18 do 21 mesecev, ter večina (nad $80 \%$ ) najstarejših malčkov, starih od 22 do 29 mesecev.

Povprečna pogostnost pripovedovanja o preteklih dogodkih in prihodnosti ter poimenovanja odsotnih predmetov in ljudi (Tabela 5) narašča s starostjo malčkov, vendar pri nižjih starostih malčkov narašča hitreje, pri višjih starostih malčkov pa se naraščanje nekoliko upočasni.

Tabela 2. Povprečni dosežki in pripadajoči 95-odstotni intervali zaupanja za dosežke dojenčkov/malčkov na posameznih področjih LRSZ: Besede in geste ter odstotek variance v dosežkih, ki je pojasnjena s starostjo

\begin{tabular}{|c|c|c|c|c|c|c|}
\hline $\begin{array}{l}\text { starost v } \\
\text { mesecih }\end{array}$ & $\begin{array}{r}\text { Izjave } \\
(\text { maks. }=28)\end{array}$ & $\begin{array}{r}\text { Besednjak } \\
\text { (razumevanje) } \\
(\text { maks. }=396)\end{array}$ & $\begin{array}{r}\text { Besednjak } \\
(\mathrm{raba}) \\
(\text { maks. }=396) \\
\end{array}$ & $\begin{array}{r}\text { Dejavnosti in } \\
\text { geste (skupaj) } \\
\text { (maks. }=63 \text { ) }\end{array}$ & $\begin{array}{r}\text { Dejavnosti in } \\
\text { geste (zgodnje) } \\
(\text { maks. }=18)\end{array}$ & $\begin{array}{l}\text { Dejavnosti in } \\
\text { geste (pozne) } \\
\text { (maks. }=45)\end{array}$ \\
\hline \multicolumn{7}{|l|}{8 in 9} \\
\hline$M$ & 7,9 & 30,6 & 1,9 & 11 & 6,5 & 4,5 \\
\hline $95 \% \mathrm{IZ}$ & {$[5,4 ; 10,4]$} & {$[16,3 ; 44,9]$} & {$[0,9 ; 2,9]$} & {$[8,1 ; 13,9]$} & {$[4,9 ; 8,2]$} & {$[3,1 ; 5,9]$} \\
\hline \multicolumn{7}{|l|}{10 in 11} \\
\hline$M$ & 17,6 & 107,4 & 13,9 & 24,4 & 11,9 & 12,5 \\
\hline $95 \% \mathrm{IZ}$ & {$[15,3 ; 20,0]$} & {$[68,7 ; 146,1]$} & {$[1,6 ; 26,2]$} & {$[20,6 ; 28,1]$} & {$[10,6 ; 13,2]$} & {$[9,6 ; 15,4]$} \\
\hline \multicolumn{7}{|l|}{12 in 13} \\
\hline$M$ & 19,2 & 147,8 & 18,5 & 31,1 & 12,6 & 18,5 \\
\hline $95 \% \mathrm{IZ}$ & {$[17,3 ; 21,2]$} & {$[119 ; 176,6]$} & {$[7,6 ; 29,4]$} & {$[28,0 ; 34,3]$} & {$[11,7 ; 13,6]$} & {$[15,9 ; 21,1]$} \\
\hline \multicolumn{7}{|l|}{14 in 15} \\
\hline$M$ & 22,7 & 199,5 & 42,3 & 37,7 & 13,8 & 23,9 \\
\hline $95 \% \mathrm{IZ}$ & {$[21,3 ; 24,0]$} & {$[172,9 ; 226,1]$} & {$[28,1 ; 56,5]$} & {$[35,2 ; 40,2]$} & {$[13,2 ; 14,4]$} & {$[21,8 ; 26,0]$} \\
\hline$\eta^{2}$ (starost) & 0,45 & 0,32 & 0,14 & 0,51 & 0,42 & 0,48 \\
\hline
\end{tabular}

Opombe: 95 \% IZ... 95-odstotni interval zaupanja za aritmetično sredino; Dejavnosti in geste (skupaj)... skupni dosežek na vseh petih področjih uporabe gest in dejavnosti; Dejavnosti in geste (zgodnje)... skupni dosežek na področjih Prve sporazumevalne geste in Igre in rutinske dejavnosti; Dejavnosti in geste (pozne)... skupni dosežek na področjih Dejanja s predmeti, Pretvarja se, da je starš in Posnemanje dejavnosti odraslih. 
Tabela 3. Prikaz odstotkov dojenčkov in malčkov, ki rabijo različne dejavnosti in geste

\begin{tabular}{lrrr}
\hline Dejavnosti in geste & zgodnje & pozne & redke \\
\hline Prve sporazumevalne geste & 67 & 8 & 8 \\
Igre in rutinske dejavnosti & 33 & 33 & 17 \\
Dejanja s predmeti & 18 & 41 & 24 \\
Pretvarja se, da je starš & 0 & 15 & 85 \\
Posnemanje dejavnosti & & & \\
odraslih & 13 & 53 & 20 \\
\hline
\end{tabular}

Rezultati, prikazani v tabeli 6, kažejo, da uporaba različnih oblik in pomenov besed s starostjo malčkov narašča, tako da večina malčkov (med $60 \%$ in $71 \%$ ), starih 28 in 29 mesecev, v govoru uporablja različne oblike in pomene besed.

\section{Povezanosti med posameznimi področji sporazumevalnih zmožnosti dojenčkov in malčkov}

Za preučitev povezanosti med posameznimi področji sporazumevalnih zmožnosti dojenčkov in malčkov, starih od 8 do 16 in od 16 do 30 mesecev, smo izračunali parcialne koeficiente korelacije, pri čemer smo kontrolirali dojenčkovo/malčkovo starost. Višina običajnih Pearsonovih koeficientov je namreč odvisna od starostnega razpona v vzorcu, ki pa je do neke mere arbitraren. Količniki, izračunani za vse starostne skupine skupaj, so prikazani v tabelah 7 in 8 .

Različna področja sporazumevalnih zmožnosti dojenčkov in malčkov, starih od 8 do 16 mesecev, se statistično pomembno ter večinoma zmerno visoko pozitivno povezujejo med seboj. Najvišje povezanosti so med zgodnjimi in poznimi gestami ter med razumevanjem besed in poznimi gestami.

Parcialni koeficienti korelacije med različnimi področji sporazumevalnih zmožnosti malčkov, starih od 16 do 30 mesecev, so bili statistično pomembni ter večinoma zmerni do visoki. V zvezi s tremi dosežki na področju Posploševanje slovničnih pravil je treba upoštevati, da dosežki niso medsebojno neodvisni. Najvišje povezanosti so bile med besednjakom malčkov in pravilnim posploševanjem slovničnih pravil, besednjakom in odsotnostjo posploševanja slovničnih pravil (te povezanosti so negativne), obliko in pomenom besed in pravilnim posploševanjem slovničnih pravil ter

Tabela 4. Povprečni dosežki in 95-odstotni intervali zaupanja za dosežke malčkov na posameznih področjih LRSZ: Besede in stavki ter odstotek variance $v$ dosežkih, ki je pojasnjena s starostjo

\begin{tabular}{|c|c|c|c|c|c|c|}
\hline $\begin{array}{l}\text { starost v } \\
\text { mesecih }\end{array}$ & $\begin{array}{r}\text { Besednjak } \\
(\text { maks. }=680)\end{array}$ & $\begin{array}{r}\text { Posploševanje } \\
\text { slovničnih } \\
\text { pravil } \\
(\text { pravilno }) \\
(\text { maks. }=39) \\
\end{array}$ & $\begin{array}{r}\text { Posploševanje } \\
\text { slovničnih } \\
\text { pravil } \\
(\text { nepravilno) } \\
(\text { maks. }=39) \\
\end{array}$ & $\begin{array}{r}\text { Posploševanje } \\
\text { slovničnih } \\
\text { pravil } \\
(\text { odsotnost) } \\
(\text { maks. }=39) \\
\end{array}$ & $\begin{array}{l}\text { Dolžina } \\
\text { stavkov }\end{array}$ & $\begin{array}{r}\text { Zapletenost } \\
\text { stavkov } \\
\text { (maks. }=37 \text { ) }\end{array}$ \\
\hline \multicolumn{7}{|l|}{16 in 17} \\
\hline$M$ & 54,3 & 1,2 & 0,5 & 37,3 & 0,5 & 1,0 \\
\hline $95 \%$ IZ & {$[22,7 ; 85,9]$} & {$[-0,2 ; 2,6]$} & {$[0,1 ; 1]$} & {$[35,5 ; 39]$} & {$[0,2 ; 0,9]$} & {$[-0,3 ; 2,3]$} \\
\hline \multicolumn{7}{|l|}{18 in 19} \\
\hline$M$ & 79,0 & 1,5 & 1,6 & 35,9 & 1,0 & 0,3 \\
\hline $95 \%$ IZ & {$[54,5 ; 103,5]$} & {$[0,5 ; 2,5]$} & {$[0,7 ; 2,6]$} & {$[34,2 ; 37,7]$} & {$[0,6 ; 1,4]$} & {$[-0,1 ; 0,6]$} \\
\hline \multicolumn{7}{|l|}{20 in 21} \\
\hline$M$ & 138,8 & 3,5 & 2,7 & 32,8 & 1,3 & 1,2 \\
\hline $95 \% \mathrm{IZ}$ & {$[109,3 ; 168,3]$} & {$[2,4 ; 4,6]$} & {$[1,7 ; 3,8]$} & {$[30,9 ; 34,6]$} & {$[0,9 ; 1,7]$} & {$[0,5 ; 1,9]$} \\
\hline \multicolumn{7}{|l|}{22 in 23} \\
\hline$M$ & 249,0 & 9,2 & 4,5 & 25,3 & 2,3 & 6,4 \\
\hline $95 \% \mathrm{IZ}$ & {$[197,8 ; 300,2]$} & {$[6,7 ; 11,7]$} & {$[3,1 ; 5,8]$} & {$[22,3 ; 28,3]$} & {$[1,8 ; 2,8]$} & {$[3,9 ; 8,8]$} \\
\hline \multicolumn{7}{|l|}{24 in 25} \\
\hline$M$ & 256,3 & 8,7 & 5,4 & 24,9 & 2,8 & 7,9 \\
\hline $95 \%$ IZ & {$[211,5 ; 301,1]$} & {$[6,4 ; 10,9]$} & {$[4,2 ; 6,7]$} & {$[22,1 ; 27,8]$} & {$[2,3 ; 3,3]$} & {$[5,2 ; 10,5]$} \\
\hline \multicolumn{7}{|l|}{26 in 27} \\
\hline$M$ & 363,6 & 14,5 & 5,8 & 18,7 & 3,8 & 12,6 \\
\hline $95 \%$ IZ & {$[307,6 ; 419,6]$} & {$[11,4 ; 17,6]$} & {$[4,3 ; 7,2]$} & {$[15 ; 22,4]$} & {$[3 ; 4,6]$} & {$[9,2 ; 16,0]$} \\
\hline \multicolumn{7}{|l|}{28 in 29} \\
\hline$M$ & 393,8 & 17,7 & 6,8 & 14,5 & 4,3 & 16,1 \\
\hline $95 \% \mathrm{IZ}$ & {$[346,8 ; 440,7]$} & {$[14,8 ; 20,6]$} & {$[5,1 ; 8,5]$} & {$[11,3 ; 17,7]$} & {$[3,7 ; 4,9]$} & {$[13,1 ; 19,1]$} \\
\hline$\eta^{2}$ (starost) & 0,39 & 0,37 & 0,18 & 0,40 & 0,34 & 0,34 \\
\hline
\end{tabular}

Opomba: Glej tabelo 2. 
Tabela 5. Odstotek malčkov, ki pripovedujejo o preteklih dogodkih in prihodnosti ter poimenujejo odsotne predmete in ljudi, v posamezni starostni skupini

\begin{tabular}{lrrrrrrr}
\hline & \multicolumn{7}{c}{ starost v mesecih } \\
\cline { 2 - 7 } & 16 in 17 & 18 in 19 & 20 in 21 22 in 23 24 in 25 & 26 in 27 & 28 in 29 \\
\hline pretekli dogodki & 18 & 23 & 55 & 67 & 76 & 86 & 90 \\
prihodnost & 30 & 41 & 59 & 78 & 85 & 86 & 98 \\
predmeti, ki niso prisotni & 68 & 86 & 88 & 94 & 93 & 93 & 94 \\
razume, če prosimo za nekaj, kar ni prisotno & 95 & 100 & 94 & 96 & 98 & 100 & 100 \\
poimenuje odsotno osebo, ki ji pripada predmet & 73 & 80 & 95 & 94 & 97 & 98 & 100 \\
\hline
\end{tabular}

Tabela 6. Odstotek malčkov v posamezni starostni skupini, ki uporabljajo različne oblike in pomene besed

\begin{tabular}{lrrrrrrr}
\hline & \multicolumn{7}{c}{ starost v mesecih } \\
\cline { 2 - 7 } & 16 in 17 & 18 in 19 & 20 in 21 & 22 in 23 & 24 in 25 & 26 in 27 & 28 in 29 \\
\hline množina & 9 & 5 & 18 & 41 & 44 & 70 & 71 \\
lastnina & 7 & 2 & 23 & 33 & 31 & 50 & 63 \\
(ne)dovršnost & 7 & 5 & 12 & 31 & 25 & 64 & 60 \\
preteklost & 2 & 0 & 14 & 29 & 34 & 55 & 60 \\
\hline
\end{tabular}

med zapletenostjo stavkov na eni strani ter besednjakom, obliko in pomenom besed in pravilnim posploševanjem slovničnih pravil na drugi strani.

\section{Razlike med spoloma v sporazumevalnih zmožnostih dojenčkov in malčkov}

Najprej smo izračunali učinek spola na sporazumevalne zmožnosti dojenčkov/dojenčic in malčkov/malčic, starih od 8 do 16 mesecev. Izvedli smo enosmerno MANCOVO za neponovljene meritve, s katero smo preučili učinek spola na vektor aritmetičnih sredin štirih odvisnih spremenljivk (besednjak: razumevanje, besednjak: raba, zgodnje geste in pozne geste), pri čemer smo nadzirali učinek starosti (v model smo kot kovariat vključili starost v mesecih). Korelacije med odvisnimi spremenljivkami so bile primerne za uporabo MANCOVE; znašale so od 0,37 (med zgodnjimi gestami in številom uporabljanih besed) do 0,72 (med poznimi in zgodnjimi gestami). Kovariančni matriki v obeh skupinah, osnovanih na spolu, se nista statistično pomembno razlikovali (Boxov $M=12,15 ; F(10$, $104860,2)=1,18 ; p=0,30)$.

Rezultati so pokazali, da smo v model upravičeno vključili starost dojenčkov/malčkov kot kovariat, saj se je izkazalo, da ima statistično pomemben in velik učinek na sporazumevalne zmožnosti dojenčkov/dojenčic in malčkov/malčic (Wilksova $\Lambda=0,47 ; F(4,146)=40,86 ; p$ $<0,001$; parcialna $\left.\eta^{2}=0,53\right)$. Ob nadzoru starosti učinek spola ni bil statistično pomemben (Wilksova $\Lambda=0,97$; $F(4,146)=1,27 ; p=0,29$; parcialna $\left.\eta^{2}=0,03\right)$.

Enako analizo smo izvedli tudi za preučitev učinka spola (ob nadzoru starosti) na vektor aritmetičnih sredin dveh odvisnih spremenljivk (besednjak in zapletenost stavkov) pri malčkih/malčicah, starih od 16 do 30 mesecev. Odvisni spremenljivki sta bili precej visoko povezani $(r=0,80)$, kovariančni matriki pa se nista statistično pomembno razlikovali (Boxov $M=1,74 ; F(3,28314968,5)$ $=0,58 ; p=0,63$ ).

Starost je tudi pri malčkih in malčicah imela statistično pomemben in srednje velik učinek na njihove sporazumevalne zmožnosti (Wilksova $\Lambda=0,61 ; F(2,354$ ) $=111,98 ; p<0,001$; parcialna $\eta^{2}=0,39$ ). Izkazalo se je, da ima tudi spol statistično pomemben, a majhen učinek na linearno kombinacijo besednjaka in zapletenosti stavkov (Wilksova $\Lambda=0,97 ; F(2,354)=4,79 ; p<0,009$; parcialna $\left.\eta^{2}=0,03\right)$. Pred izvedbo univariatnih ANCOV smo preverili, ali v primeru obeh odvisnih spremenljivk drži predpostavka o homogenosti varianc. Ugotovili smo, da predpostavka drži tako v primeru besednjaka $(F(1,356)$ $=0,19 ; p=0,66)$ kot tudi v primeru zapletenosti stavkov $(F(1,356)=0,09 ; p=0,76)$. Naknadni univariatni analizi sta pokazali, da se malčice $(M=246,6 ; S D=190,6)$ in malčki $(M=197,1 ; S D=189,0)$ statistično pomembno razlikujejo zgolj v velikosti besednjaka $(F(1,355)=9,25$; $M S E=22441,1 ; p=0,003)$, pri čemer je ta učinek precej majhen (parcialna $\eta^{2}=0,03$; Cohenov $d=0,26$ ). Tudi pri

Tabela 7. Parcialni koeficienti korelacije med področji LRSZ: Besede in geste

\begin{tabular}{|c|c|c|c|}
\hline & $\begin{array}{r}\text { Besednjak } \\
(\mathrm{raba})\end{array}$ & $\begin{array}{r}\text { Dejavnosti in geste } \\
\text { (zgodnje geste) }\end{array}$ & $\begin{array}{r}\text { Dejavnosti in geste } \\
\text { (pozne geste) }\end{array}$ \\
\hline Besednjak (razumevanje) & $0,47^{* *}$ & $0,48^{* *}$ & $0,52^{* *}$ \\
\hline Besednjak (raba) & & $0,20^{*}$ & $0,18^{*}$ \\
\hline Dejavnosti in geste (zgodnje geste) & & & $0,50^{* *}$ \\
\hline
\end{tabular}

${ }^{*} p<0,05 ;{ }^{* *} p<0,01$. Glej tudi opombo pod tabelo 2 . 
Tabela 8. Parcialni koeficienti korelacije med področji LRSZ: Besede in stavki

\begin{tabular}{|c|c|c|c|c|c|c|c|c|c|}
\hline & & 2 & 3 & 4 & 5 & 6 & 7 & 8 & Zapletenost stavkov \\
\hline 1 & Besednjak & $0,49^{* *}$ & $0,71^{* *}$ & $0,81^{* *}$ & $0,37^{* *}$ & $-0,82^{* *}$ & $0,50^{* *}$ & $0,66^{* *}$ & $0,70^{* *}$ \\
\hline 2 & $\begin{array}{l}\text { Pretekli in prihodnji dogodki ter } \\
\text { odsotni predmeti in osebe }\end{array}$ & & $0,32^{* *}$ & $0,35^{* *}$ & $0,29^{* *}$ & $-0,41^{* *}$ & $0,55^{* *}$ & $0,41^{* *}$ & $0,23^{* *}$ \\
\hline 3 & Oblika in pomen besed & & & $0,74^{* *}$ & $0,20^{* *}$ & $-0,68^{* *}$ & $0,33^{* *}$ & $0,56^{* *}$ & $0,70^{* *}$ \\
\hline 4 & $\begin{array}{l}\text { Posploševanje slovničnih pravil } \\
\text { (pravilno) }\end{array}$ & & & & $0,18^{* *}$ & $-0,89^{* *}$ & $0,36^{* *}$ & $0,64^{* *}$ & $0,74^{* *}$ \\
\hline 5 & $\begin{array}{l}\text { Posploševanje slovničnih pravil } \\
\text { (nepravilno) }\end{array}$ & & & & & $-0,61^{* *}$ & $0,39^{* *}$ & $0,30^{* *}$ & 0,06 \\
\hline 6 & $\begin{array}{l}\text { Posploševanje slovničnih pravil } \\
\text { (odsotnost) }\end{array}$ & & & & & & $-0,47^{* *}$ & $-0,65^{* *}$ & $-0,62^{* *}$ \\
\hline 7 & Združevanje besed & & & & & & & $0,65^{* *}$ & $0,28^{* *}$ \\
\hline 8 & Dolžina stavkov & & & & & & & & $0,60^{* *}$ \\
\hline
\end{tabular}

${ }^{*} p<0,05 ;{ }^{* *} p<0,01$.

zapletenosti stavkov so malčice $(M=7,19 ; S D=9,95)$ dosegle višji dosežek kot malčki $(M=5,67 ; S D=9,46)$, vendar razlike med njimi niso bile statistično pomembne $(F(1,355)=2,91 ; M S E=65,9 ; p=0,089)$, pa tudi velikost učinka je bila $\mathrm{v}$ primerjavi $\mathrm{z}$ besednjakom še nekoliko manjša (parcialna $\eta^{2}=0,01$; Cohenov $d=0,16$ ).

\section{Razprava}

Rezultati so pokazali, da slovenski dojenčki začenjajo razumeti besede med 8 . in 9. mesecem starosti; pri tej starosti se je večina dojenčkov že odzvala na svoje ime ali na prepoved $z$ besedo »ne«. V povprečju so dojenčki te starosti razumeli tudi nekaj preprostih izjav (npr. »Priden.« ali »Gremo pa pa.«), razumevanje preprostih izjav pa je s starostjo malčkov hitro naraščalo, saj so 14- in 15-mesečni malčki razumeli že večino izmed navedenih preprostih izjav. Podobno kot to ugotavljajo nekateri drugi avtorji (npr. Bates in Goodman, 2001; Fenson idr., 2004), dobljeni rezultati kažejo, da razumevanje govora v razvoju predhodi govornemu izražanju. Večina dojenčkov, starih 8 in 9 mesecev, kljub temu da so že razumeli nekatere preproste izjave, še ni ponavljala besed, ki jih je slišala in $\mathrm{z}$ besedami tudi ni poimenovala stvari $\mathrm{v}$ svoji neposredni okolici. Dobljeni izračuni so pokazali, da je približno polovica dojenčkov, starih 10 in 11 mesecev, in večina malčkov, starih 14 in 15 mesecev, rabila besede. Podobno ugotavljajo tudi drugi avtorji, da večina malčkov govori prvo besedo $\mathrm{v}$ starosti med 12. in 20. mesecem (npr. Fernald idr., 2001; Tomasello in Bates, 2001). Dejstvo, da dojenčki in malčki besede prej razumejo, kot jih rabijo, potrjuje tudi primerjava o tem, koliko besed dojenčki/ malčki določene starosti razumejo in rabijo. V splošnem gre za razmeroma velike razlike $\mathrm{v}$ številu besed, ki jih dojenčki in malčki določene starosti razumejo in rabijo: 8in 9-mesečni dojenčki, ki so v povprečju rabili 2 besedi, so razumeli 31 besed; 14 - in 15 -mesečni malčki, ki so v povprečju rabili 42 besed, so razumeli 200 besed. Hkrati pa pomembna pozitivna povezanost med številom besed, ki so jih dojenčki in malčki razumeli in rabili, kaže na to, da so dojenčki/malčki, ki so razumeli več besed, tudi rabili več besed.

Dobljeni rezultati kažejo tudi na razmeroma hiter porast besednjaka (besed, ki jih dojenčki in malčki rabijo) v celotnem obdobju med 8 . in 30. mesecem starosti. Po ocenah mam so prve besede govorili dojenčki, stari 8 in 9 mesecev, malčki, stari 12 in 13 mesecev, so $\mathrm{v}$ povprečju govorili 18 besed, malčki, stari 18 in 19 mesecev, 79 besed, malčki, stari 24 in 25 mesecev, 256 besed, besednjak malčkov, starih 28 in 29 mesecev, pa je v povprečju obsegal že 394 besed. Rezultati so primerljivi z izsledki avtorjev (npr. Bates in Goodman, 2001; Siegler, 1998) o hitrem razvoju besednjaka v obdobju malčka, ko se besednjak malčkov lahko poveča za nekaj besed dnevno. Večji porast besed, ki bi lahko, čeprav gre za prečno in ne vzdolžno pridobljene podatke, kazal na dva skoka $\mathrm{v}$ razvoju besednjaka, smo zabeležili pri malčkih, starih od 18 do 25 mesecev (besednjak malčkov se je povečal z 79 na 256 besed) in malčkih, starih od 25 do 30 mesecev (besednjak se je povečal z 256 na 394 besed). Ti rezultati so primerljivi z ugotovitvami $\mathrm{E}$. Bates in J. C. Goodman (2001), ki navajata, da se pri angleško govorečih malčkih prvi skok v razvoju besednjaka pojavi med 16. in 20. mesecem, drugi pa med 24. in 30. mesecem malčkove starosti. Na podlagi dobljenih rezultatov lahko prav tako zaključimo, da so bile med dojenčki/malčki znotraj posamezne starostne skupine razmeroma velike individualne razlike $\mathrm{v}$ velikosti besednjaka, o katerih poročajo tudi nekateri drugi avtorji (npr. Fernald idr., 2001; Tomasello in Bates, 2001).

Dobljeni rezultati so nadalje pokazali, da so dojenčki $\mathrm{v}$ drugi polovici prvega leta starosti že uporabljali geste za sporazumevanje z drugimi, na kar kažejo izsledki tudi nekaterih drugih avtorjev (npr. Karmiloff in KarmiloffSmith, 2001). Osem- in 9-mesečni dojenčki, vključeni $\mathrm{v}$ vzorec, so namreč pri sporazumevanju $\mathrm{z}$ drugimi uporabljali prve sporazumevalne geste (npr. pokaže »tiho« tako, da položi prst na ustnice) in so se vključevali $\mathrm{v}$ igre in rutinske dejavnosti (npr. se igra izštevanke). Nekoliko redkeje so uporabljali geste, ki se pojavijo 
pozneje $\mathrm{v}$ razvoju, to so dejanja s predmeti, pri katerih gre za uporabo predmetov na konvencionalen način (pije iz skodelice) oz. predsimbole, kot jih poimenuje L. McCune-Nicolich (1981), in simbolna dejanja (npr. »vozi« avto tako, da obrača volan). Uporaba sporazumevalnih in simbolnih gest ter dejavnosti je s starostjo dojenčkov in malčkov naraščala, pri čemer je bil porast uporabe poznih gest hitrejši kot porast uporabe zgodnjih gest. Ugotovitve naše raziskave so pokazale, da so že 10- in 11-mesečni dojenčki uporabljali, čeprav zelo redko, tudi simbolne geste, s katerimi so simbolizirali dejanja ali predmete v igri (npr. hrani dojenčka, ga položi v posteljo). Delež malčkov, ki so že oblikovali predmetne zamenjave, se je s $5 \%$ pri 10 -in in 11-ih mesecih starosti zvišal na $38 \%$ pri 14 -ih in 15-ih mesecih starosti. Podrobnejša analiza značilnosti pojavljanja posameznih gest in dejanj je pokazala, da so bile simbolne geste, ki vključujejo pretvarjanje v vlogi starša in posnemanje dejavnosti odraslih, v splošnem bolj značilne za starejše malčke in se zato verjetno $\mathrm{v}$ razvoju pojavijo kasneje kot sporazumevalne geste, kot so npr. prve sporazumevalne geste in preproste igre in rutinske dejavnosti.

Rezultati so pokazali, da se posamezna področja sporazumevalnih zmožnosti dojenčkov in malčkov v obdobju med 8. in 30. mesecem starosti med seboj pomembno pozitivno povezujejo. Dojenčki in malčki, ki so uporabljali več sporazumevalnih in simbolnih gest in dejavnosti, so imeli tudi bolj obsežen besednjak oz. so razumeli in rabili več besed v primerjavi z dojenčki in malčki, ki so uporabljali manj sporazumevalnih in simbolnih gest in dejavnosti. Podobno navaja več avtorjev (npr. Brooks in Meltzoff, 2008; Messinger idr., 1999), in sicer, da se uporaba gest pri dojenčkih in malčkih statistično pomembno povezuje $\mathrm{z}$ velikostjo njihovega trenutnega in kasnejšega besednjaka. Posebnega pomena za razvoj govora je uporaba gest $\mathrm{v}$ simbolni igri, saj tako govor kot simbolna igra od otroka zahtevata zmožnost simbolnega predstavljanja (npr. Goodwin in Acredolo, 1993; McCuneNicolich, 1981). Dojenčki in malčki, stari od 8 do 16 mesecev, za katere so mame ocenile, da so razumeli in govorili več besed kot njihovi vrstniki, so razumeli tudi več preprostih izjav odraslega (npr. »Si lačen?« ali »Ne delaj tega.«); uporabljali so več zgodnjih in poznih gest; pogosteje so uporabljali prve sporazumevalne geste, ki se nanašajo na geste dajanja, kazanja in iztegovanja ter konvencionalne sporazumevalne geste, ki označujejo dojenčkovo/malčkovo namerno sporazumevanje $\mathrm{z}$ drugimi; vključevali so se v večje število iger in izvajali več rutinskih dejavnosti z odraslimi; izvajali so več dejanj s predmeti, ki kažejo na njihovo razumevanje predmetov in ustrezne uporabe le-teh; izvajali so več simbolnih dejanj pretvarjanja v vlogi starša in več dejanj, s katerimi so posnemali dejavnosti odraslega. Dobljeni rezultati kažejo na pozitivno povezanost med besednjakom starejših malčkov in slovnično strukturo njihovega govora, na kar opozarjajo tudi drugi avtorji, ki so v svoje raziskave vključevali angleško govoreče malčke (npr. Bates in Goodman, 2001; Tomasello in Bates, 2001). Malčki, stari od 16 do 30 mesecev, za katere so naše mame ocenile, da imajo večji besednjak, oz. govorijo več besed kot njihovi vrstniki, so z besedami tudi pogosteje referirali na dogodke, ki so se zgodili v preteklosti ali se bodo $\mathrm{v}$ prihodnosti ter na odsotne osebe in predmete. Ti malčki so prav tako pogosteje rabili različne oblike in pomene besed (obrazila, pripone in predpone za oblikovanje množine, lastnine, dovršnih in nedovršnih glagolov ter pomožni glagol »biti« za oblikovanje preteklega časa). Bolj obsežen besednjak, ki je hkrati vključeval tudi več različnih besednih vrst, je malčkom omogočal, da so oblikovali daljše stavke $\mathrm{z}$ več besedami in slovnično bolj zapletene stavke. Rezultati so primerljivi z ugotovitvami avtorjev (npr. Tomasello in Bates, 2001), da je razvoj besednjaka pomembno povezan z razvojem uporabe slovničnih pravil jezika. Nove besede, ki jih malčki usvojijo, jim omogočajo, da na različne načine združujejo in oblikujejo besede $\mathrm{v}$ stavke.

Dobljeni rezultati so nadalje pokazali, da gre v obdobju malčka za starostne razlike tudi $\mathrm{v}$ slovnični strukturi malčkovega govora. Malčki pa se z naraščajočo starostjo v govoru tudi vedno bolj odmikajo od trenutne situacije in neposrednega okolja. Podobno kot sta ugotovila Crain in Lillo-Martin (1999), da malčki, stari približno leto in pol, začenjajo združevati dve besedi $\mathrm{v}$ besedno zvezo, tudi naši rezultati kažejo, da je približno polovica malčkov, starih od 18 do 21 mesecev, že združevala dve ali več besed, medtem ko je besede v stavke združevala večina malčkov, starih od 22 do 29 mesecev. Stavki, ki so jih malčki različnih starostnih skupin v obdobju med 16 in 30 mesecem govorili, so bili vedno daljši in bolj zapleteni. Medtem, ko so malčki, stari od 16 do 21 mesecev, v povprečju še vedno oblikovali enobesedne stavke, se je povprečna dolžina stavka v vsaki starostni skupini malčkov nekoliko zvišala, tako da so malčki, stari 28 in 29 mesecev, v povprečju oblikovali stavke, sestavljene iz štirih besed, stavki pa so bili tudi slovnično vedno bolj zapleteni. Razvoj slovnične strukture govora malčkov se kaže tudi $\mathrm{v}$ ugotovljenih razlikah med starostnimi skupinami v vedno pogostejšemu pravilnemu in nepravilnemu posploševanju slovničnih pravil, in sicer pri tvorjenju množinskih samostalnikov in spreganju glagolov. Podobno kot to velja za angleško govoreče malčke (Fenson idr., 2004), se je tudi na vzorcu slovensko govorečih malčkov pokazalo, da nepravilno posploševanje slovničnih pravil s starostjo malčkov narašča in kaže na razvojni napredek $\mathrm{V}$ primerjavi $\mathrm{z}$ odsotnostjo posploševanja, torej na to, da je malček že usvojil določeno slovnično pravilo, vendar ga še ne zna pravilno posplošiti na vse besede. Tudi nekateri drugi avtorji ugotavljajo (npr. Siegler, 1998; Smith in Cowie, 1993), da v obdobju do 30. meseca starosti malčki hitro usvajajo slovnična pravila jezika, kar jim omogoča tudi to, da govorijo o odsotnih predmetih in preteklih ter prihodnjih dogodkih (Browne, 1996). Malčki, stari 16 in 17 mesecev, vključeni v naš vzorec, so razmeroma redko pripovedovali o preteklih dogodkih (18\% malčkov te starosti), najpogosteje pa so razumeli, če jih nekdo prosi za nekaj, kar ni neposredno 
prisotno $\mathrm{v}$ njihovem okolju ( $95 \%$ malčkov te starosti). Velika večina (nad $90 \%$ ) malčkov pa je pri starosti 28 in 29 mesecev že pripovedovala o preteklih in prihodnjih dogodkih, poimenovala predmete, ljudi in osebe, ki trenutno niso bile prisotni, razumela, če jih nekdo prosi za nekaj, česar ni v sobi ter poimenovala odsotno osebo, ki ji pripada določen predmet. Starostne razlike so se izražale tudi v uporabi različnih oblik in pomena besed. Medtem ko je razmeroma majhen delež malčkov, starih od 16 do 21 mesecev, uporabljal različne oblike in pomene besed, je večina malčkov, starih 28 in 29 mesecev, tvorila množino, označevala lastnino, uporabljala dovršne in nedovršne glagole, da bi označila dejavnost, ki je zaključena ali še traja in ustrezno uporabljala glagole v preteklem času.

Ugotovitve o učinku spola na sporazumevalne zmožnosti dojenčkov in malčkov se le delno skladajo z ugotovitvami drugih avtorjev (npr. Bornstein in Haynes, 1998; D’Odorico, Carubbi, Salerni in Calvo, 2001, Fenson idr., 1994; Macaulay, 1977), ki kažejo, da se govor deklic razvija hitreje od govora dečkov, in sicer deklice hitreje spregovorijo, prej usvojijo slovnico jezika, oblikujejo daljše izjave in imajo bolj obsežen besednjak. Primerjava sporazumevalnih zmožnosti dojenčkov in dojenčic ter malčkov in malčic, vključenih v naš vzorec, je pokazala, da se le-ti med seboj niso statistično pomembno razlikovali $\mathrm{v}$ številu besed, ki jih razumejo in govorijo ter uporabi sporazumevalnih in simbolnih gest med 8. in 16. mesecem starosti. Dojenčki/malčki so rabili nekoliko več besed kot dojenčice/malčice, medtem ko so dojenčice/malčice uporabljale nekoliko več poznih gest kot dojenčki/malčki. Glavni učinek spola na sporazumevalne zmožnosti je bil statistično pomemben $\mathrm{v}$ starostni skupini starejših malčkov/malčic, pri čemer je podrobnejša analiza razlik med spoloma pokazala, da se malčki in malčice statistično pomembno razlikujejo zgolj $\mathrm{v}$ velikosti besednjaka. Malčice so govorile več besed kot malčki. O nekoliko drugačnih izsledkih poročajo Eriksson in sodelavci (2012), ki so v metaanalizi 10 raziskav, ki je vključevala vzorec 13783 ne-angleško govorečih dojenčkov in malčkov, starih od 8 do 30 mesecev, preučevali učinek spola na zgodnje sporazumevalne zmožnosti, ocenjene s CDI (Fenson idr., 2004), prirejenim v različne jezike. Avtorji so ugotovili, da so dojenčice in malčice, stare od 8 do 16 mesecev, rabile statistično pomembno več sporazumevalnih gest in govorile več besed kot enako stari dojenčki in malčki, med njimi pa ni bilo statistično pomembnih razlik v številu besed, ki so jih razumeli. Avtorji so podobne razlike med spoloma, ki so s starostjo malčkov naraščale, ugotovili tudi v skupini malčkov in malčic, starih od 16 do 30 mesecev, in sicer so malčice govorile statistično pomembno več besed kot malčki, prav tako pa so malčice v večjem deležu kot malčki že združevale besede v stavke.

Na podlagi vseh dobljenih rezultatov lahko zaključimo, da gre $\mathrm{v}$ razvojnih obdobjih dojenčka in malčka za pomembne spremembe $\mathrm{V}$ razvoju sporazumevalnih zmožnostih, in sicer tako $\mathrm{z}$ vidika uporabe nebesednih znakov (npr. gest in simbolnih dejanj) kot tudi besednjaka in slovnice jezika. Hkrati pa rezultati kažejo, da so različna področja sporazumevalnih zmožnosti med seboj povezana.

Čeprav je predstavljena raziskava prva, ki natančneje preučuje značilnosti zgodnjega govora in sporazumevalnih zmožnosti slovensko govorečih dojenčkov in malčkov, moramobiti priposploševanju ugotovitev previdni; podatki o značilnostih sporazumevalnih zmožnosti dojenčkov in malčkov so bili zbrani prečno in ne vzdolžno, kar nam onemogoča podajanje zaključkov o razvojnih zakonitostih govornega razvoja. Razmeroma majhni vzorci dojenčkov in malčkov posameznih starosti, zaradi česar smo morali pri obdelavi podatkov posamezne starostne skupine združevati, ne omogočajo starostno zelo natančne primerjave sporazumevalnih zmožnosti. Na dobljene rezultate bi lahko vplivale tudi značilnosti vzorca glede na izobrazbo staršev, ki je nekoliko pristranski v smislu nesorazmerno velikega deleža visoko izobraženih staršev in majhnega deleža staršev $\mathrm{z}$ nizko (osnovnošolsko) izobrazbo. Omejitev velja tudi za zaključevanje o učinku spola na sporazumevalne zmožnosti dojenčkov in malčkov, saj je bilo v vzorec vključenih razmeroma majhno število dojenčic in dojenčkov ter malčic in malčkov. Nenazadnje moramo biti pri oblikovanju zaključkov pozorni tudi na to, da so podatki o sporazumevalnih zmožnostih dojenčkov/malčkov pridobljeni na podlagi ocen mam. Na njihove ocene lahko $\mathrm{v}$ določeni meri učinkujejo nekateri dejavniki, kot so mamina izobrazba, znanje jezika ter poznavanje govornega razvoja dojenčkov/malčkov (npr. Fenson idr., 2004; Marjanovič Umek, Fekonja idr., 2011; Tardif, Gelman in Xu, 1999).

\section{Literatura}

Akhtar, N. (2001). Acquiring basic word order: Evidence for data-driven learning of syntactic structure. V M. Tomasello in E. Bates (ur.), Language development. The essential readings (str. 187-202). Oxford: Blackwell.

Bates, E. in Goodman, J. C. (2001). On the inseparability of grammar and the lexicon: Evidence from acquisition. V M. Tomasello in E. Bates (ur.), Language development: The essential readings (str. 134-162). Oxford: Blackwell.

Bates, E., Dale, P. in Thal, D. (1995). Individual differences and their implications for theories of language development. V P. Fletcher in B. MacWhinney (ur.), Handbook of child language (str. 96-151). Oxford: Basil Blackwell.

Bates, E., Marchman, V., Thal, D., Fenson, L., Dale, P., Reznick, J. S., Reilly, J. in Hartug, J. (1994). Developmental and stylistic variation in the composition of early vocabulary. Journal of Child Language, 21, 85-124.

Belsky, J. in Most, R. K. (1981). From exploration to play: A cross-sectional study of infant free play behaviour. Developmental Psychology, 17, 630-629.

Bornstein, M. H. in Haynes, O. M. (1998). Vocabulary competence in early childhood: Measurement, latent 
construct, and predictive validity. Child Development, 69(3), 654-671.

Bornstein, M. H., Cote, L. R., Maital, S., Painter, K., Par, S.-Y., Pascual, ... Vyt, A. (2004). Cross-linguistic analysis of vocabulary in young children: Spanish, Dutch, French, Hebrew, Italian, Korean, and American English. Child Development, 75(4), 1115-1139.

Brooks, R. in Meltzoff, A. N. (2008). Infant gaze following and pointing predict accelerated vocabulary growth through two years of age: A longitudinal, growth curve modelling study. Journal of Child Language, 35, 207-220.

Browne, A. (1996). Developing Language and Literacy 3-8. London: Paul Chapman Publishing.

Caselli, M. C., Casadio, P. in Bates, E. (2001). Lexical development in English and Italian. V M. Tomasello in E. Bates (ur.), Language development: The essential readings (str. 76-110). Oxford: Blackwell.

Crain, S. in Lillo-Martin, D. (1999). An introduction to linguistic theory and language acquisition. Oxford: Blackwell.

D’Odorico,L.in Carrubi, S.(2003). Prosodic characteristics of early multi-word utterances in Italian children. First Language, 23(1), 97-116.

D’Odorico, L., Carrubi, S., Salerni, N. in Calvo, V. (2001). Vocabulary development in Italian children: A longitudinal evaluation of quantitative and qualitative aspects. Journal of Child Language, 28, 351-372.

Dale, P. S., Bates, E., Reznick, J. S. in Morisset, C. (1989). The validity of a parent report instrument of child language at twenty months. Journal of Child Language, 16, 239-249.

Doswell, G., Lewis, V., Sylva, K. in Boucher, J. (1994) Validational data on the Warwick Symbolic Play Test. European Journal of Disorders of Communication, 29, 289-298.

Eimas, P. D. in Miller, J. L. (1991). A constraint on the discrimination of speech by young infants. Language and Speech, 34(39), 251-263.

Eriksson, M., Marschik, P. B., Tulviste, T., Almgren, M., Pereira, M. P., Wehberg, S., ... Gallego, C. (2012). Differences between girls and boys in emerging language skills: Evidence from 10 language communities. British Journal of Developmental Psychology, 30(2), 326-343.

Feldman, H. M., Dollaghan, C. A., Campbell, T. F., Kurs-Lasky, M., Janosky, J. E. in Paradise, J. L. (2000). Measurement properties of the MacArthur Communicative Development Inventories at ages one and two years. Child Development, 71(2), 310-322.

Fenson, L., Dale, P., Reznick, J. S., Bates, E., Thal, D. in Pethick, S. (1994). Variability in early communicative development. Monographs of the Society for Research in Child Development, 59(242).

Fenson, L., Dale, P. S., Reznick, J. S., Thal, D., Bates, E., Hartung, J. P., Pethick, S. in Reilly, J. S. (2004). MacArthur Communicative Development Inventories: User's guide and technical manual. Baltimore: Paul H. Brooke.
Fernald, A., Pinto, J. P., Swingley, D., Weinberg, A. in McRoberts, G. W. (2001). Rapid gains of verbal processing by infants in the 2 nd year. V M. Tomasello in E. Bates (ur.), Language development: The essential readings (str. 49-56). Oxford: Blackwell.

Goodwin, S. W. in Acredolo, L. P. (1993). Symbolic gesture versus word: Is there a modality advantage for onset of symbol use? Child Development, 64, 688-701.

Harris, J. (1993). Early language development. London: Routledge.

Hoff, E. (2001). Components of word learning skill. Poster, predstavljen na X. Evropski konferenci o razvojni psihologiji, Švedska, Uppsala.

Iverson, J. M., Caprici, O. in Caselli, C. M. (1994). From communication to language in two modalities. Cognitive Development, 9, 23-43.

Jusczyk, P. W. in Hohne, E. A. (1997). Infants' memory for spoken words. Science, 277, 1984-1986.

Karmiloff, K. in Karmiloff-Smith, A. (2001). Pathways to language. Cambridge: Harvard University Press.

Lewis, V., Boucher, J., Lupton, L. in Watson, S. (2000). Relationships between symbolic play, functional play, verbal and non-verbal ability in young children. International Journal of Language and Communication Disorders, 35(1), 117-127.

Lyytinen, P., Poikkeus, A.-M. in Laakso, M.-L. (1997). Language and symbolic play in toddlers. International Journal of Behavioral Development, 21, 289-302.

Macaulay, R. (1977). The myth of female superiority in language. Journal of Child Language, 5, 353-363.

Mandel, D. R., Jusczyk, P. W. in Pisoni, D. B. (1995). Infants' recognition of the sound patterns of their own names. Psychological Science, 6, 315-318.

Marchman, V. in Bates, E. (1994). Continuity in lexical and morphological development: A test of the critical mass hypothesis. Journal of Child Language, 21(2), 339-366.

Marjanovič Umek, L., Fekonja, U., Kranjc, S. in Bajc, K. (2008). The effect of children's gender and parental education on toddler language development. European Early Childhood Education Research Journal, 16(3), 325-342.

Marjanovič Umek, L., Fekonja, U., Podlesek, A. in Kranjc, S. (2011). Assessing toddler language competence: Agreement of parents' and preschool teachers' assessments. European Early Childhood Education Research Journal, 19(1), 21-43.

Marjanovič Umek, L., Fekonja Peklaj, U., Sočan, G. in Komidar, L. (2011). Ocenjevanje sporazumevalnih zmožnosti dojenčkov in malčkov. Lista razvoja sporazumevalnih zmožnosti: Besede in geste in Lista razvoja sporazumevalnih zmožnosti: Besede in stavki. Priročnik Assessment of communicating abilities of infants and toddlers: Words and geatures, and The list of development of communicative abilities: Words and sentences. Manual.]. Ljubljana: Center za psihodiagnostična sredstva. 
McCune, L. (1995). A normative study of representational play in the transition to language. Developmental Psychology, 31(2), 198-206.

McCune-Nicolich, L. (1981). Toward symbolic functioning: Structure of early pretend games and potential parallels with language. Child Development, 52, 785-797.

Mehler, J in Dupoux, E. (1994). What infants know: The new cognitive science of early development. Cambridge, MA: Blackwell.

Messer, D. (1999). The development of communication and language. V D. Messer in S. Millar (ur.), Exploring developmental psychology (str. 62-82). London: Arnold.

Messinger, D. S., Fogel, A. in Dickson, K. L. (1999). What's in a smile? Developmental Psychology, 35, 701-708.

Nelson, K. (1973). Structure and strategy in learning to talk. Monographs of the Society for Research in Child Development, 38(149).

Nelson, K. (1996). Language in cognitive development: The emergence of the mediated mind. Cambridge: Cambridge University Press.

O'Reilly, A. W. in Bornstein, M. N. (1993). Caregiverchild interaction in play. New Directions for Child and Adolescent Development, 59, 55-66.

Oppenheim, D., Emde, R. N. in Wamboldt, F. S. (1996). Associations between 3-year-olds narrative coconstructions with mothers and fathers and their story completions about affective themes. Early Development and Parenting, 5(3), 149-160.

Owens, R. E. (1996). Language development. Columbus, $\mathrm{OH}$ : Charles E. Merrill.

Parise, E., Friederici, A. D. in Striano, T. (2010). »Did you call me? « 5-month-old infants own name guides their attention. PLoS ONE, 5(12), e14208.

Reich, P. A. (1986). Language development. New Jersey: Prentice-Hall.

Reynell, J. K. (1979). RDLS First edition manual. Oxford: NFER-Nelson.

Reznick, J. S. in Goldfield, B. A. (1994). Diary vs. representative checklist assessment of productive vocabulary. Journal of Child Language, 21, 465-472.

Siegler, R. S. (1998). Children's thinking. New Jersey: Prentice Hall.

Smith, P. K. in Cowie, H. (1993). Understanding children's development. Oxford, Cambridge: Blackwell.

Tardif, T., Gelman, S. A. in Xu, F. (1999). Putting the "noun bias" in context: A comparison of English and Mandarin. Child Development, 70(3), 620-635.

Tomasello, M. (2001). Perceiving intentions and learning words in the second year of life. V M. Tomasello in E. Bates (ur.), Language development: The essential readings (str. 112-128). Oxford: Blackwell.

Tomasello, M. in Bates, E. (2001). General introduction. V M. Tomasello in E. Bates (ur.), Language development: The essential readings (str. 1-11). Oxford: Blackwell.
Whitehead, M. (1999). Supporting language and literacy development in the early years. Buckingham: Open University Press.

Whitehead, M. R. (2005). Language and literacy in the early years. London: SAGE Publications. 